\title{
correspondence
}

\section{Triggered lightning hazards}

SiR,-Following the publication of our paper entitled "Artificially triggered lightning above land" (Nature, 257, $212 ; 1975)$ we hear that several specialists elsewhere are thinking of embarking on similar programmes. Therefore, safety considerations prompt us to discuss some recent findings about unexpected lightning strokes to the ground in the vicinity of such experiments.

Among a total of 45 successful triggerings using a rocket carrying a thin steel wire attached to the ground, the following sequence of events occurred on six occasions. First, when the ascending rocket was more than $150 \mathrm{~m}$ high, the device attracted a small current detected only because the vaporised wire emitted a faint glow. This glow passed through a maximum and then began to decrease. Between 40 and 80 milliseconds later, a bright flash occurred striking the ground or an object in the near neighbourhood. The maximum distance between the expected and actual point at which the lightning struck has been as much as $145 \mathrm{~m}$.

Evidence obtained at various distances with still and movie cameras reveals that in the upper region the arrangement of the luminous branches is typical of upward development, whereas in the lower part the streamer shapes indicate downward propagation. Therefore it is likely that the main channel is created by propagation in both directions, starting from the upper portion of the wire.

The photograph is of an anomalously triggered flash striking the ground near our experimental site. Another flash which struck a pine grove damaged several trees and in the next twelve months these and adjacent ones died.

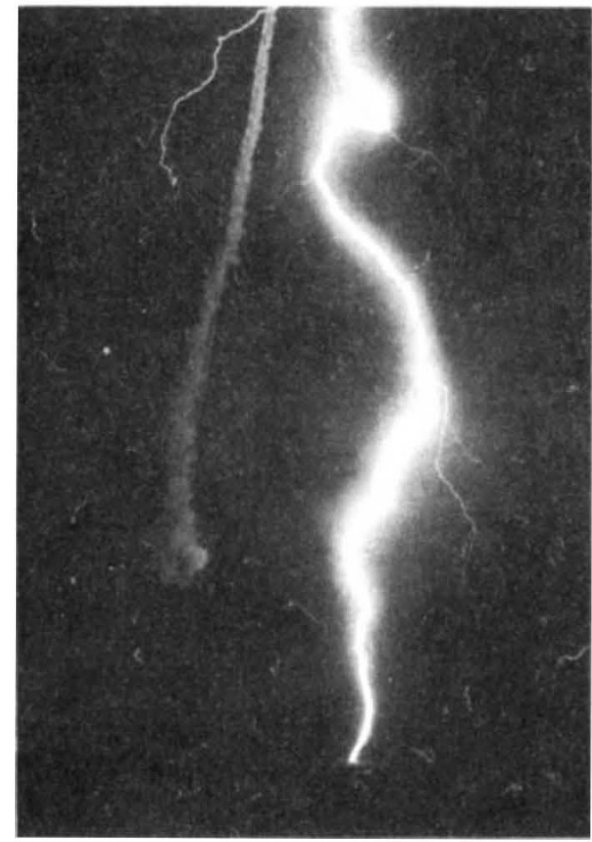

The anomalous triggering effect is of great interest but calls for more stringent safety measures in the experimental area. A detailed report is available on request.

Yours faithfully,

R. FIEUX

Electricité de France,

Division des Etudes et Recherches, F.92 140 Clamart

P. Hubert

Commissariat à l'Energie Atomique, F-91 190 Saclay, France

\section{CPSU Congress}

SIR-A notable feature of the recent Twenty-Fifth Congress of the Soviet Communist Party is the adherence of the hard-core communists to Karl Marx's principle of the scientific interpretation of history.
Mr Pytor Masherov, party chief of the Byelorussian Republic, in an attack on some Western communists, said: "To say Marxism-Leninism has become antiquated is like saying that Newton's 300-year-old law of gravity is antiquated too".

$\mathrm{Mr}$ Gus Hall, the US Communist Party Chief, went a step further. $\mathrm{He}$ said: "The ideas of Marxism-Leninism penetrate the whole contents of Leonid Brezhnev's speech like the bright ray of a powerful laser".

Perhaps in the following congress we shall hear of quasars, black-holes, big bangs, etc. As a scientific community we should feel elated! Yours faithfully, SREEDHAN RoY

\section{Department of Mechanical}

Engineering,

University College,

London, UK

\section{The pace of life}

SiR,--Bornstein and Bornstein's paper (February 19, page 557) leads to fascinating conclusions. Their data suggest that in the case of the smallest human conurbation (one person) the average walking speed is 0.05 feet $\mathrm{s}^{-1}$ $\left(50 \mathrm{~m} \mathrm{~h}^{-1}\right.$ or $\left.1.3 \mathrm{~km} \mathrm{~d}^{-1}\right)$. Fortunately this quantity is not negative. On the other hand, its value is small and a value of zero is probably compatible with the experimental data. This may be the explanation of the fact that those few people who are known to live alone show a propensity for spending extended periods of time on the tops of poles, in caves or in barrels.

Yours faithfully,

J. A. EADES

H. H. Wills Physics Laboratory,

Bristol University,

Bristol 8, UK

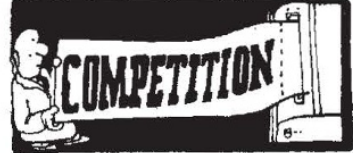

Competition 6

LitTLE jingles are being put in advertisements by the British Metrication Board to speed the public's passage into a metrical world. Specimen-

Two and a quarter pounds of jam, Weigh about a kilogram.
A prize of $£ 10$ is offered for the best rhyming couplet on one of those forgettable SI units. Closing date for entries is April 21.

Competition 5 demanded an anagram on a scientific concept to rival the irreverent one on Nessiteras rhombopteryx. There was a large entrymost people couldn't stop when they got into the swing of things.

To W. A. F. Watson of Aberdeen goes $£ 6$ for "Fie, Mendel! Result cheating, score all peas!" (These DNA molecules are self replicating).

H. J. Taylor of Sheffield wins $£ 4$ for "Natural Science men musn't interpolate inapt ideas" (Entia non sunt multiplicanda praeter necessitatem).

C. K. Thornhill of Orpington received honorable mention for " $O$, so in fact $\mathrm{G}$ not t-variant?" (Constant of gravitation). Hard luck on several good candidates whose anagrams weren't. 